\title{
ARTES
}

\section{UIRAÚNA GÛYRAUNA}

\section{Igor Alexandre Barcelos Graciano Borges}

Universidade de Brasília (UnB), Brasil

igoralexandre@hotmail.com

DOI: https://doi.org/10.26512/caleidoscopio.v4i1.28714

Recebido em: 17/12/2019

Aceito em: 04/07/2020

Publicado em dezembro de 2020

Minha terra tem racismo,

Onde estrala o chicote,

Avê Maria! Sinhô, gorjeiam

os pásso-pretos,

Nosso céu tem mais fumaça,

Herança do café e da cana-de-açucar,

Nossos bosquês pegam fogo, no bolso mais

Dinheiro e no coração mais fortuna,

Nas cinzas da minha gente, sozinho, penso,

Mais prazer e menor preço,

Vale a carne negra no mercado,

Minha terra tem de tudo, de tudo eu tenho lá,

Os pásso-pretos cantam triste, mais bonito que o sabiá,

Minha terra cheia de horrores,

Que tais encontro cá,

Queria ir a passárgada, pois lá, eu não hei de chorar,

A vala funda prometida, Deus não permita que morra lá,

Já me basta o abismo, na margem, que vós-mercê, jogaram nós tudo, tá?

Todos aos prantos, garados em troncos, 
Matadouro lustrado à sangue,

Que não se encontra em qualquer terra,

Ôh meu Deus, quem me dera, ouvir qu'inda só um minuto,

A voz da liberdade gritando: - Igualdade!

Aos quatro cantos do mundo.

\section{Biografia do autor}

Igor Alexandre Barcelos Graciano Borges é doutorando em Literatura pela Universidade de Brasília (UnB), mestre em Letras pela Universidade Estadual de Mato Grosso do Sul (UEMS), possui graduação em Letras Português/Inglês e suas respectivas Literaturas pela Universidade Estadual de Goiás (UEG), é músico e poeta. Desde meados de sua adolescência escreve poemas, contos e composições musicais. Procura entender a Arte em seus aspectos técnicos, estéticos e teóricos, em outras palavras, em toda sua amplitude, o que o leva a compor e escrever sempre que possível. 